\title{
Selection and Application of Ecosystem Evaluation Index for Ranking Inland Wetland Conservation
}

\author{
Soo-Dong Lee ${ }^{1}$, Mi-Jeong $\mathrm{Kim}^{2}$, and Ji-Suk Kim ${ }^{3 *}$ \\ ${ }^{1}$ Department of Landscape Architecture, Gyeongnam National University of Science and Technology, 52725, South Korea \\ ${ }^{2}$ Division of Ecological Conservation, National Institute of Ecology, 33657, South Korea \\ ${ }^{3}$ Institute of Comprehensive Bio Industrial, Pusan National University, 50463, South Korea
}

\begin{abstract}
Wetlands are damaged or destroyed by natural processes or artificial interferences. In order to restore their function, it is desirable to establish conservation, restoration and management measures on the basis of comprehensively collected and analyzed data of natural ecosystem characteristics and damage conditions. The purpose is to provide an evaluation index that can reflect the biological and physical characteristics such as the inhabited wildlife, degree of terrestrialization, land use change, etc. Due to the evaluation index should be simplicity of measurement, applicability, and cost efficiency as well as useful for improving the new information is obtained, so we consider the physical and biological characteristics. In order to reflect the ecological integrity and qualitative aspects such as disturbance levels, suitability as biological habitats, etc., biodiversity (landscape units, wildlife inhabit), naturalness (biotope, basin ecosystem), rarity (major plant species emergence, major animal species inhabit), and potential for damage (distribution of pollutant by distance, degree of internal damage) was selected as an evaluation index. The conservation value of Hwapo (23 points) and Samrangjin wetland (21 points), which had low number of species and populations, was low due to high potential for damage like green house, bare land etc. On the other hand, Daepyeong (34 points) and Bacsil wetland (32 points), which have worthy biodiversity, showed high conservation value, while their own area was narrow, but the endangered wildlife (Cygnus cygnus, Anser fabalis, and Euryale ferox) was appeared. Habitat disturbances, such as reduced area or internal damage, can drastic changes at population, ecosystem, and community levels. Hwapo and Samrangjin wetland, which have high damaged potential, are included. The recoverability of wetland ecosystem functions depend on the resistance and regenerative power of the system itself, so maintaining integrity of biodiversity-rich wetlands will have priority over restoration.
\end{abstract}

Key words: biodiversity, endangered wildlife, evaluation index, damage potential

\section{I . Introduction}

Wetlands are swamp, fen, peatland or water, whether natural or artificial, permanent or temporary, with water that is static or flowing, fresh, brackish or saline, including areas of marine water of which depth of water does not exceed $6 \mathrm{~m}$ at low tide, and artificial wetland (Ramsar convention Secretariat, 2013). In FWS (Cowardin System), wetlands are defined as transitional lands between terrestrial and aquatic systems where the water table is usually at or near the surface or the land is covered by shallow water, and lands where saturation with water is the

Received on May 17, 2017. Revised on June 14, 2017.

Accepted on June 19, 2017.

*Comesponding author: gstone1@hanmail.net

This work was supported by Gyeongnam National University of

Science and Technology Grant in 2016. dominant factor determining the nature of soil development and the types of plant and animal communities living in the soil and on its surface (Cowardin et al., 1979). Tiner (1996) stated that wetlands might be comprehensively applicable to all habitat types that are temporarily, periodically, seasonally and permanently wet, and typical wetlands included lakes, rivers, brackish water zone and freshwater wetlands. In South Korea, wetlands are referred to as estuaries, mud, swamps, ponds, lagoons, pools, moors, marshland, peatland and marsh (Kwon, 2013), and in the Wetlands Conservation Act, the term "wetlands" is defined as inland wetlands or coastal wetlands which are areas permanently or temporarily covered with fresh water, brackish water or salt water. In order to be determined as wetland, the reproducibility in physical, chemical and biological forms, continuous submergence or saturation should be confirmed, and identifying the distribution of soil plants and water plants is 
a useful diagnostic method, but it is quite difficult to distinguish wetlands due to the diversity of types, natural dynamics and ambiguity in the relationship with adjacent water systems (Committee on Characterization of Wetlands, 1995). Mitsch and Gosselink (2000) asserted that three basic elements including the existence of water, unique soil conditions and water plants needed to be confirmed, and especially large plants were one of factors deciding the type of wetland (Van der Valk, 2012). The purpose of each country or international organization to make continuous efforts to define and classify wetlands (Tiner, 1989) includes the confirmation of an ecologically similar habitat unit, systematic classification for enabling resource management, confirmation of unit for the purpose of inventory, and mapping and permission of terms and concept on a national scale.

Wetland functions are defined as a process or series of processes that take place within a wetland. These include the storage of water, transformation of nutrients, growth of living matter, and diversity of wetland plants (U.S. Geological Survey, 1996), and they have value for the wetland itself (Mitsch and Gosselink, 2000). The unique functions of wetlands include productivity, self-sustainability and biological diversity (Parker, 1984), and the directly and indirectly beneficial functions to humans in terms of biological, chemical and physical aspects include the protection of water quality, reduction of flood damages, recharging of underground water, circulation of nutrients, deposition of floating materials and habitat for wildlife and native plants (Kang, 2004; Kent et al., 1992; Koo and Kim, 2001; Minnesota Pollution Control Agency, 2006). In terms of biological habitat, wetlands are used as spawning and breeding grounds for wild birds and these wetlands are also important for food, resting, protection and social interaction (Manral and Khudsar, 2013; Stewart, 1996). Also, plants growing in wetlands provide food, resting place and spawning grounds to wildlife both directly and indirectly (Jones et al., 2009) and also help local residents to make their living. In terms of hydrologic aspect, wetlands play a fundamental role to mitigate the effects of extreme rain and maintain the minimum flow during a dry season as well as an substantial role for mitigating water problems by improving water usability (Koeln, 1992; Jensen et al., 1993; Teferi et al., 2010; Morris and Camino, 2011). Abundant water creates the ecosystem with a high biological diversity and plays a key role such as the prevention of regional flood and erosion, purification of water and recycling of nutrients (Jones et al., 2009). The above functions of wetland can be grouped into the habitat for wildlife and native plants, hydrology to reduce damage that may occur due to rainfall and the purification of water to reduce floating matters and pollutants, and wetlands provide many direct and indirect benefits such as supply of clean drinking water and leisure space in addition.

Although wetlands are important ecosystems for providing the prevention of regional flood and erosion, purification of water and recycling of nutrients, wetlands undergo degradation in the 20th century due to hydraulic changes such as the drainage for cultivation, inflow of point pollution sources and non-point pollution sources, extinction of native species due to the invasion of foreign species and drainage (Jones et al., 2009). It turned out that more than $50 \%$ of wetlands globally and approximately $80 \%$ of wetlands in Europe, North America and East Asia where the population was concentrated have disappeared due to such direct and indirect harmful effects (Verhoeven et al., 2006; Naiman et al., 1995). It was caused by climate change, excavation of river bed and sea level rise on a geological time scale (Dugan, 1993), but the recent loss of wetlands occurred due to human conduct such as the reclamation and drainage for cultivation, digging of peat for fuel and gardening, construction of flood control structures and channel straightening (Stewart, 1996; Jones et al., 2009; Verhoeven et al., 2006), and such human conduct gave adverse impacts such as loss of biological diversity, reduction of biogeochemical cycle and reduction of water supply, causing the reduction of overall ecosystem service (Buijse et al., 2005). In the end, abuse and damage were actual problems and these problems resulted from lack of social recognition of multifaceted values (Berhanu, 2012), so it was necessary to improve such recognition and investigate internal and external impact factors generated as the result of human conduct at the same time in order to conserve and manage wetlands efficiently.

With regard to the wetlands evaluation, such evaluation needed to be supported by scientific investigations and researches, and Hruby et al. (1999) presented a condition of availability, cost efficiency, no result change according to a small property change and ease of information improvement. The evaluation 
method was developed from the quantification of functions (Novitzki et al., 1996), and it can be classified into WET (wetland evaluation technique) of Adamus et al. (1987) to evaluate individual wetland comprehensively by focusing on its function of physical, chemical and biological characteristics, EMAP wetlands (Novitzki 1994, U.S. Geological Survey, 1996) for evaluating the condition of wetland on a regional and national scale and HGM (Hydrogeomorphic Approach) (Brinson, 1993; Smith et al., 1995) which is improved from the WET method for evaluating physical, chemical and biological functions. Qualitative evaluation is technically possible but it may be limited if the target is a wide area, so it is necessary to classify the level into the landscape scale, regional scale and individual wetland (Minnesota Pollution Control Agency, 2006). Also, the structural characteristics, improvement of water quality and provision of habitat should be included in order to evaluate the ecological process (Haering and Galbraith, 2010; Koo and Kim, 2001; Hruby, 2001), and the landscape context, land or water surface size, vegetation or soil status should be included in order to evaluate the ecological healthiness (Cowardin et al., 1979; Faber-Langendoen et al., 2012). In terms of biological aspect, wild birds are influenced by water quality, vegetation type and the depth of water, so it is necessary to reflect flora such as exotic species and indigenous species for qualitative evaluation (Stewart, 1996; Ervin et al., 2006). The disturbance level and morphological properties are emphasized in term of evaluation of plant community integrity (Index of plant community integrity) although fresh water wetlands are quite complicated due to the diversity of natural vegetation community (Johnston et al., 2009; 2008; Mollard et al., 2013). Each researcher presents various items and standards for wetlands evaluation because the type of wetlands and the evaluation goals are different, and it is advisable to find an index which enables the trace of factors causing a change and a change in the ecosystem suffering from stress shocks under the standard called stability.

Wetlands are damaged or destroyed by natural processes or artificial interferences. In order to restore their function, it is desirable to establish conservation, restoration and management measures on the basis of comprehensively collected and analyzed data of natural ecosystem characteristics and damage conditions (Turner et al., 1993). And, the evaluation index for selecting the priority order is advisable as its efficiency, that is, simplicity of measurement, applicability and easiness of analysis are higher (Kent et al., 1992; Breckenridget et al., 1995; Turner et al., 1993). Therefore, this study aims at presenting the wetlands evaluation index that could reflect biological and physical status such as the investigation result of specific natural ecosystem status in wetlands, level of terrestrialization and effects due to changes in the use of surrounding lands efficiently and comprehensively.

\section{Material and Method}

\section{Research Scope and procedure}

Wetlands have been recognized as useless lands for a long period of time and such lands have been evaluated as the target for development, so the loss of a wide area through landfill occurs around the world. Therefore, a study to establish correct direction for the awareness improvement project and policies regarding wetlands is very important. Inland wetlands, mountainous wetlands and coastal wetlands are distributed in Gyeongsangnam-do Province, and inland wetlands are located in main Nakdonggang River and near tributaries including Huanggang River, Namgang River and Miryanggang River, mountainous wetlands are located in the eastern mountainous region and coastal wetlands are located in the south coast (Park et al., 2007). In this study, the selection of evaluation index and conservation and management priorities was carried out based on the investigation and analysis results of ecological condition and damage potential targeting 6 inland wetlands from 15 wetlands with a high value that could be used as the resource for ecological education and tourism in the wetlands roadmap in Gyeongsangnam-do Province among 103 inland wetlands, 13 mountainous wetlands and 50 coastal wetlands confirmed from the previous investigation by considering the uniformity of evaluation standards.

Among the target areas for study, Jungyang wetland and Bacsil wetland were located in the riverside of Hwanggang River, Daepyeong wetland and Jilnal wetland were located in the riverside of Namgang River, Hwapo wetland was located in the side of Hwapocheon Stream and Samrangjin wetland was located in the riverside of Nakdonggang River, receiving 
the influence of rivers both directly and indirectly. Hwapo wetland was distributed over Jinyeong-eup, Jillye-myeon and Hallim-myeon in Gimhae-si, Gyeongsangnam-do Province with the total area of 2,708,539.16 $\mathrm{m}^{2}$, Samrangjin wetland was distributed over Songji-ri, Samnangjin-eup, Miryang with the total area of 363,956.87 $\mathrm{m}^{2}$, Jungyang wetland was distributed over Jeongyang-ri, Hapcheon-gun with the total area of $511,157.62 \mathrm{~m}^{2}$, Bacsil wetland was distributed over Yongji-ri, Yongju-myeon, Hapcheon-gun with the total area of 287,764.15 $\mathrm{m}^{2}$, Daepyeong wetland and Jilnal wetland were distributed over Daesong-ri, Beopsu-myeon, Haman-gun with the total area of 98,195.00 $\mathrm{m}^{2}$ and 178,725.33 $\mathrm{m}^{2}$ respectively (Figure 1). Hwapo wetland, Samrangjin wetland, Jungyang wetland and Bacsil wetland were located in the riverside, bordering rice paddies and forests, and Daepyeong wetland and Jilnal wetland surrounded by forests maintained the function to supply water for agricultural use. The management plan of restoration and experience center for Jungyang wetland, restoration and learning facility for Hwapo wetland, ecological restoration for Bacsil wetland, restoration and visiting facility for Jilnal wetland and Samrangjin wetland and restoration and promotion for Daepyeong wetland was established (Park et al., 2007) but the facilities such as decks and public toilets were mainly installed with no consideration of ecological characteristics.

\section{Survey and analysis method}

This research was divided into 3 steps including the status investigation and analysis, selection of evaluation index and selection of conservation and management priorities through scoring (Table 1). In the environmental ecology status investigation and analysis, the investigation and analysis data of existing vegetation and land coverage status and inhabitation status of mammal, wild birds, amphibians, butterfly and dragonfly were compiled. In order to set the evaluation unit, the plants ecosystem corresponding to the basis of ecosystem was classified by considering the stratification and natural characteristics of dominant species based on the existing vegetation and land coverage. For the evaluation index to compare the ecological value of wetlands and impact area, the categories were selected by considering the existing literature and the standards investigated or acquirable from the field were presented for sub categories. The detailed standards were set based on data that could be obtainable through the field investigation by considering the opinions of Hruby et al. (1999),

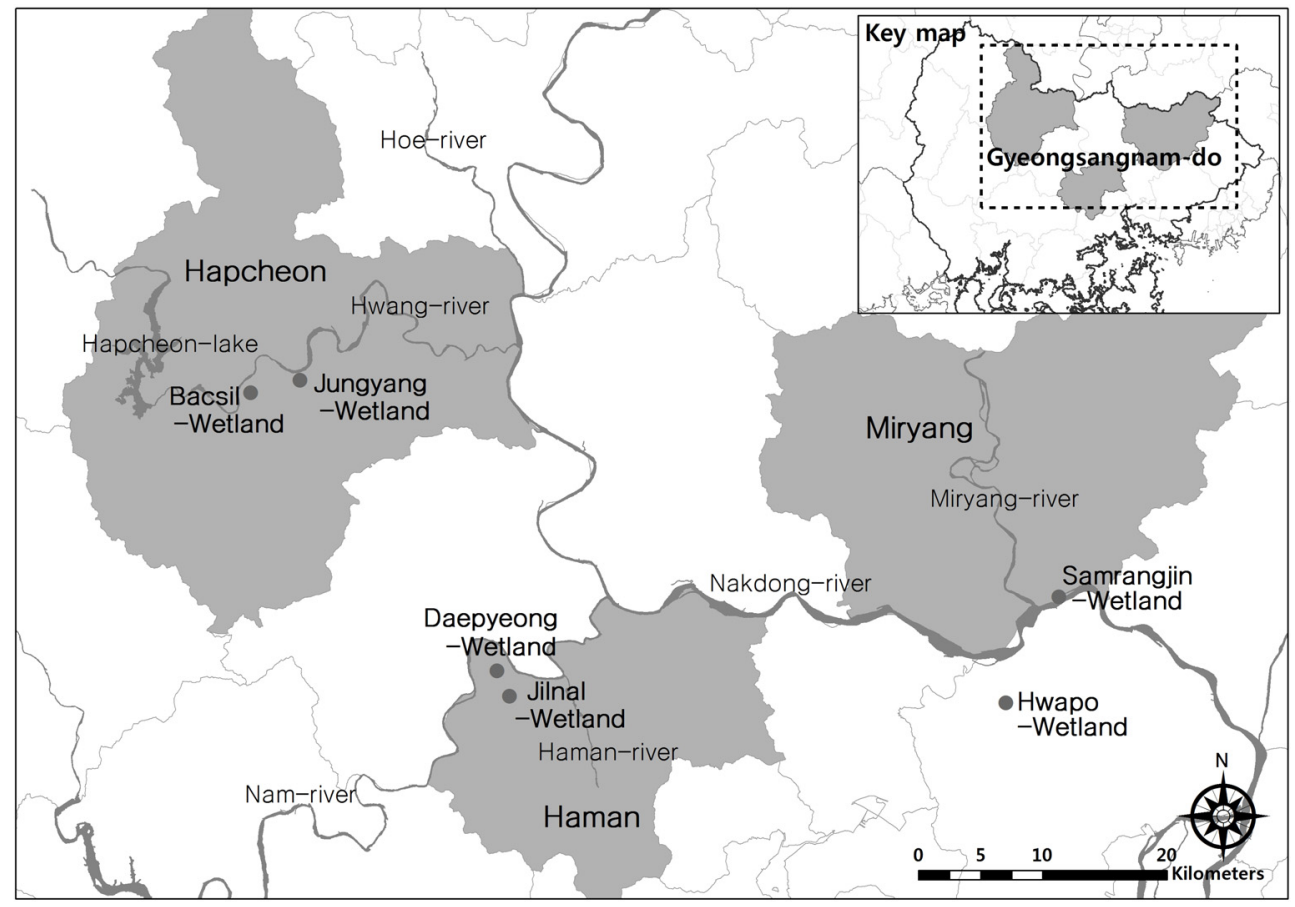

Fig. 1. The location map of research site. 
Table 1. Research and evaluation procedure for ecological characteristic identification.

\begin{tabular}{|c|c|c|}
\hline Step & Item & Detail research contents \\
\hline \multirow{2}{*}{$\begin{array}{l}1^{\text {st }} \text { step: } \\
\text { Researching and analysing } \\
\text { environmental ecology } \\
\text { status }\end{array}$} & $\begin{array}{l}\text { Natural } \\
\text { environment }\end{array}$ & $\begin{array}{l}\text { - Vegetational ecology: Actual vegetation and land use pattern within wetland and impact area } \\
\text { - Animal ecology: mammals, wild birds, amphibians, butterfly, and dragonfly emergence and } \\
\text { live status within wetland and impact area }\end{array}$ \\
\hline & biotope typology & $\begin{array}{l}\text { - Characterization of habitat based on actual vegetation and land co } \\
\text { of stratification at vegetation, naturalness of dominant species, }\end{array}$ \\
\hline \multirow{2}{*}{$\begin{array}{l}2^{\text {nd }} \text { step: } \\
\text { Selection of the valuation } \\
\text { index }\end{array}$} & Selection criteria & - Selection of item and criteria that can be analyzed through field surveys \\
\hline & Evaluation item & $\begin{array}{l}\text { - Criteria that can be evaluate the physical and biological characteristics of wetlands, based on } \\
\text { the biotope typification data, flora and fauna distribution status etc. }\end{array}$ \\
\hline $\begin{array}{l}3^{\text {rd }} \text { step: } \\
\text { Selection the order of } \\
\text { priority }\end{array}$ & $\begin{array}{l}\text { Priority of } \\
\text { conservation and } \\
\text { management }\end{array}$ & $\begin{array}{l}\text { - Comprehensive assessment of wetlands based on evaluation indicators and items to prioritize } \\
\text { wetland conservation and management }\end{array}$ \\
\hline
\end{tabular}

Kent et al. (1992), Breckenridget et al. (1995), Turner et al. (1993) asserting that the evaluation index should have the measurement simplicity, applicability, cost efficiency and such result needed to be updatable when new information was obtained. In the selection of evaluation index and selection of conservation and management priorities through scoring, the priorities were drawn by evaluating the physical and biological properties of 6 wetlands comprehensively based on the evaluation index and standards.

In the environmental ecology status investigation and analysis, existing vegetation and land use pattern were investigated in order to evaluate the ecological quality and potential of vegetational ecology. First of all, the investigation and classification standards of Lee and Kim (2009) were utilized in the studies related to water pollution in rivers and lakes, but it was judged that such standards were not able to explain complicated land use pattern in the surrounding areas of lakes and wetlands with 6 categories and 23 sub categories. Therefore, the areas with no vegetation were classified by considering the land use type, and the areas with vegetation were classified by considering the vegetational physiognomy of plant or dominant species based on the standards of Lee and Kim (2009) and Lee et al. (2015). In order to investigate and analyze the habitat relationship of mammals, wild birds, amphibians, reptiles and butterfly in the animal ecology, farmlands and waterways located inside wetlands and impact area were observed, and than the location of their appearance was mapped and the list of species was prepared. In the line-transect, wild animals appeared within $25 \mathrm{~m}$ from the left and right sides of the investigation path after sunrise were observed using the naked eye, binoculars and fieldscope and the name, population and main behavior of species were investigated using their crying, form of flying and footprints (Bibby et al., 2000; Kwak, 2007). In addition, 5 m-wide and $10 \mathrm{~m}$-long (10 sites) enumeration districts in the waterfront area were installed and the list and population of species for dragonfly were determined by considering the vegetation types such as cattail and wild rice and the representative land use types such forest and farmland. For the biotope typology, producers corresponding to the basis of ecosystem were categorized first based on the existing vegetation and land coverage status (McIntosh, 1986) and the farmland biotope was sub-categorized according to the characteristics of habitat (humidity). And, the installation of facilities based on ecological characteristics, grassland and wetland biotope was sub-categorized according to the indigenous characteristics of dominant species and the characteristics of habitat. And, forest biotope was sub-categorized according to the autogenous characteristics of dominant species, planting status and the characteristics of habitat (Lee, 2007; Lee and Kim, 2009).

The wetlands evaluation was developed from the quantification of functions (U.S. Geological Survey, 1996), and the method to evaluate individual wetland comprehensively with a focus on its biological, physical and chemical functions was suggested in common, so such method was considered (Adamus et al., 1987; Brinson 1993; Smith et al., 1995). With regard to the index, each researcher presented various methods. However, the index for evaluating the ecological process and function that could reflect the structural characteristics, improvement 
of water quality and the provision of habitat (Koo and Kim, 2001; Hruby, 2001; Haering and Galbraith, 2010) and the index that could reflect the landscape context, size of land and water surface and vegetation or soil status enabling the evaluation of ecological healthiness (Cowardin et al., 1979; Faber-Langendoen et al., 2012) were selected in this study. Also, it was judged that the flora needed to be reflected on the index for qualitative evaluation since the fresh water wetlands were influenced by the disturbance level and morphological properties (Johnston et al., 2009; Mollard et al., 2013) in terms of evaluation of plant community integrity (Index of plant community integrity) and wild birds were influenced by water quality, vegetation type and depth of water although such wetlands were too complicated to be reflected on the index due to the diversity of natural vegetation community (Stewart, 1996; Ervin et al., 2006). In the end, it was judged that it was reasonable to select the standards enabling the evaluation of physical structure, chemical properties of water and biological properties for the wetlands evaluation. However, only physical and biological characteristics were considered in this study in accordance with the opinions of Kent et al. (1992), Breckenridget et al. (1995), Turner et al. (1993) and Hruby et al. (1999) asserting that the measurement simplicity, availability, cost efficiency as well as ease of information improvement needed to be available for selecting the evaluation index. For the physical characteristics, the naturalness and potential for damage were selected as index in order to reflect the area of wetlands, internal and external vegetation area and surrounding land use in terms of ecological integrity evaluation (Mollard et al., 2013). For biological characteristics, the biological diversity, naturalness of vegetation and rarity were selected as index in order to reflect qualitative aspects and evaluate the disturbance level(Johnston et al., 2009) and suitability as biological habitats (Stewart, 1996) (Figure 2).

The evaluation index was set based on data acquirable through the field investigation and analysis in order to draw the conservation and management priorities through the comparison of ecological value of wetlands. For the convenience of evaluation, the Likert 5-point scale was used for scoring of evaluation index, and the biotope unit was set as the basic unit for the valuation based on the evaluation standard study in the biotope unit presented by Wittig and Schreiber (1983). The priority order was presented after summing up the score of biological diversity, naturalness, rarity and potential for damage. However, physical, chemical and biological factors to decide the function or value of wetland were presented, but there was no study considering the relative importance of wetland, and weight was reflected by classifying detailed evaluation index into comparative index and fixed index, so the wetlands were compared in this study through simple summing up.

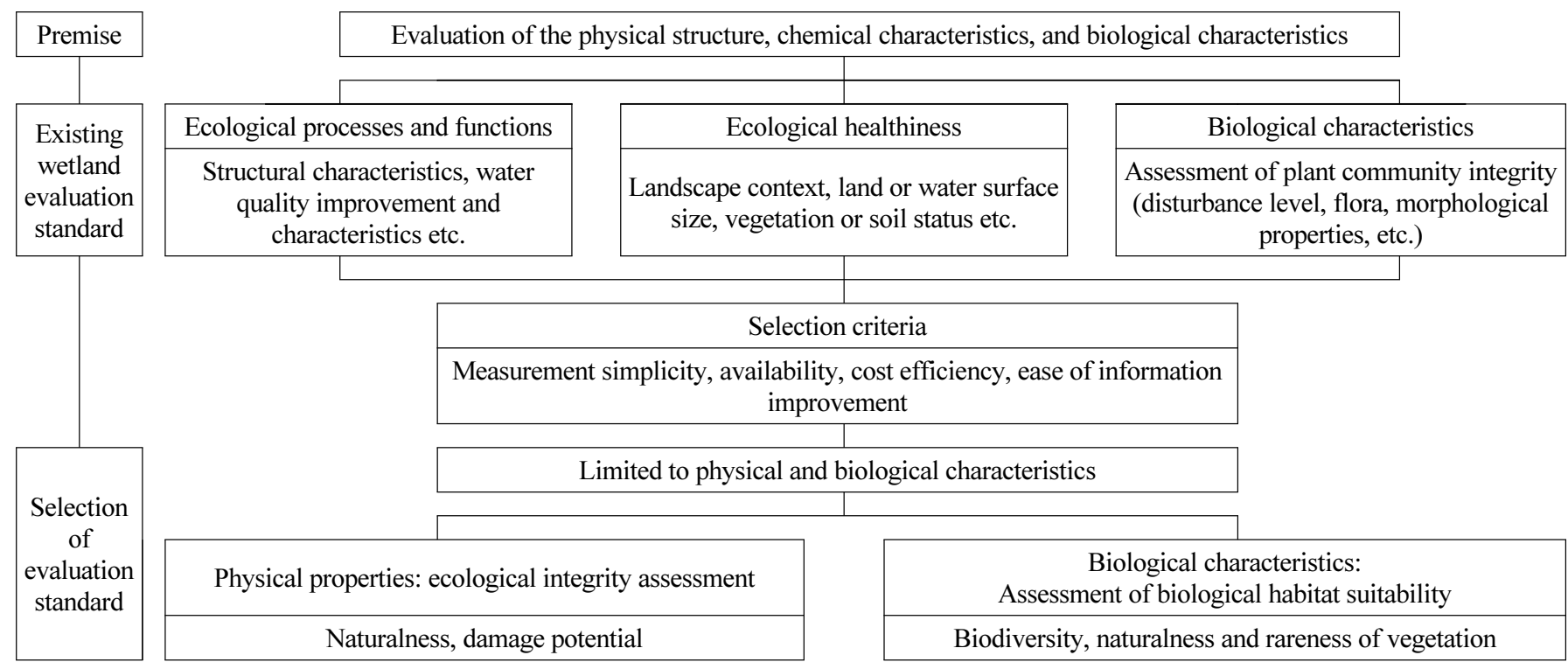

Fig. 2. Evaluation index selection system 


\section{Result and Discussions}

\section{Ecological characteristics}

\section{1) Flora and fauna}

In order to evaluate wetland, it is necessary to find an index which enables the trace of factors causing the process of change and a change in the ecosystem suffering from stress shocks (Turner et al., 1993), and animal and plant diversities are one of reasons that wetlands have been protected globally (Verhoeven et al., 2006), so these animal and plant diversities are highly important as index to evaluate biological diversity, naturalness and potential for damage in the long term. Also, wetlands function as the habitat for wild animals and plants, so the animal and plant diversity can be considered as an important index to evaluate qualitative aspects (U.S. Geological Survey, 1996; Minnesota Pollution Control Agency, 2006). Since plant species could reflect the environmental healthiness of wetlands and were sensitive to a environmental change (Mattews et al., 2009), the appearance of flora, rare species and protected species enabling direct confirmation of changes in water quality or internal environments were identified. According to the list of plant species appeared in wetlands (Table 3), 40 families, 87 genera and 95 species appeared from Bacsil wetland, showing the largest number of species, followed by 37 families, 86 genera and 105 species from Hwapo wetland, 40 families, 85 genera and 98 species from Daepyeong wetland, 40 families, 87 genera and 95 species from Jungyang wetland and 32 families, 78 genera and 95 species from Samrangjin wetland, and 32 families, 62 genera and 70 species appeared from Jilnal wetland, showing the lowest number of plant species. For naturalized species, 27 species from Hwapo wetland and Samrangjin wetland respectively, 21 species from Jungyang wetland, 17 species from Daepyeong wetland, 14 species from Jilnal wetland and 12 species from Bacsil wetland were observed, indicating that the naturalness of Bacsil wetland was most

Table 3. Synthesis of the wildlife observation status at inland wetlands.

\begin{tabular}{|c|c|c|c|c|c|c|c|}
\hline \multicolumn{2}{|c|}{ Classification } & Jungyang wetland & Bacsil wetland & Hwapo wetland & Samrangin wetland & Daepyeong wetland & Jilnal wetland \\
\hline \multirow{3}{*}{ Flora } & Species No. & $\begin{array}{c}\text { 40families 87genera } \\
\text { 95species }\end{array}$ & $\begin{array}{c}\text { 45families 98genera } \\
\text { 131species }\end{array}$ & $\begin{array}{c}\text { 37families 86genera } \\
\text { 105species }\end{array}$ & $\begin{array}{c}\text { 32families 78genera } \\
\text { 95species }\end{array}$ & $\begin{array}{c}\text { 40families } 85 \text { genera } \\
\text { 98species }\end{array}$ & $\begin{array}{c}\text { 32families 62genera } \\
70 \text { species }\end{array}$ \\
\hline & $\mathrm{N} / \mathrm{E} / \mathrm{R}$ & $21 /-/ 2$ & $12 / 2 / 1$ & $27 / 1 / 2$ & $27 /-/ 1$ & $17 /-/ 3$ & $14 /-/ 2$ \\
\hline & Note & Euryale ferox* & - & Euryale ferox* & - & Euryale ferox* & Euryale ferox* \\
\hline \multirow{2}{*}{ Mammalia } & Species No. & 4 & 6 & 4 & 5 & 4 & 1 \\
\hline & Note & Felis bengalensiseuptilura* & Felis bengalensiseuptilura* & Felis bengalensiseuptilura* & Felis bengalensiseuptilura* & Felis bengalensiseuptilura* & - \\
\hline \multirow{6}{*}{ Wild bird } & Winter & 17 species 310 individuals & 15 species 563individuals & 20species 610individuals & 26species 416individuals & 18species 150 individuals & 10species 230individuals \\
\hline & Spring & 21 species 197 individuals & 17species 179 individuals & 20 species 365 individuals & 13 species 142 individuals & 14 species 57 individuals & 9species 104individuals \\
\hline & Summer & 24 species 241 individuals & 17 species 115 individuals & 28species 570individuals & 17species 164 individuals & 11species 86individuals & 11species 140individuals \\
\hline & Autumn & 30species 664individuals & 20species 609individuals & 25 species 417 individuals & 15species 268 individuals & 22species 260individuals & 23species 342individuals \\
\hline & sub-total & 50species 972individuals & 40species 914individuals & 41species 1257 individuals & 38 species 557individuals & 36species 382 individuals & 28species 563individuals \\
\hline & Note & $\begin{array}{c}\text { Accipiter soloensis, Falco } \\
\text { tinnunculus }(* * \text { No. 323), } \\
\text { Aix galericulata }(* * \text { No. 327), } \\
\text { Buteo buteo*, } \\
\text { Anser fabalisserrirostris*, } \\
\text { Anser erythropus }{ }^{*}\end{array}$ & $\begin{array}{l}\text { Accipiter nisus }(* * \text { No. } 323) \text {, } \\
\text { Falco tinnunculus } \\
(* * \text { No. } 323), \\
\text { Aix galericulata }(* * \text { No. } 327)\end{array}$ & $\begin{array}{c}\text { Buteo buteo*, Falco } \\
\text { tinnunculus }(* * \text { No. 323) } \\
\text { Aix galericulata }(* * 327)\end{array}$ & $\begin{array}{l}\text { Falco tinnunculus } \\
\quad(* * \text { No. } 323)\end{array}$ & $\begin{array}{c}\text { Buteo buteo*, Falco } \\
\text { tinnunculus (** No. 323) }\end{array}$ & $\begin{array}{l}\text { Falco tinnunculus } \\
\quad(* * \text { No. } 323)\end{array}$ \\
\hline \multirow{2}{*}{$\begin{array}{l}\text { Amphibian } \\
\text { and reptile }\end{array}$} & Species No. & 8 & 7 & 3 & 4 & 2 & 2 \\
\hline & Note & Pelophylax chosenicus* & Pelophylax chosenicus* & - & - & - & - \\
\hline \multirow{4}{*}{ Butterfly } & Spring & 3species 10individuals & 11species 25 individuals & 5 species 27individuals & 3species 47individuals & 4species 13 individuals & 5species 12individuals \\
\hline & Summer & 2species 7individuals & 9species 23individuals & 4species 18 individuals & 3 species 23 individuals & 5 species 5individuals & 5species 8individuals \\
\hline & Autumn & 5 species 13 individuals & 6species 26individuals & 5species 29individuals & 8species 54individuals & - & 3species 7individuals \\
\hline & sub-total & 6species 21 individuals & 19species 52individuals & 8species 44individuals & 8species 82individuals & 8species 17individuals & 9species 19individuals \\
\hline \multirow{4}{*}{ Dragonfly } & Spring & 11species 181 individuals & 19species 181 individuals & 15 species 264individuals & 11species 178 individuals & 16species207individuals & 13species 106individuals \\
\hline & Summer & 17species 189 individuals & 19species 497individuals & 28 species 255 individuals & 21 species 150 individuals & 13species99individuals & 13species 147individuals \\
\hline & Autumn & 7species 52individuals & 6species 58individuals & 7species 117individuals & 3species 59individuals & 4species 27individuals & 5 species 38 individuals \\
\hline & sub-total & 23species 343 individuals & 28species 625 individuals & 28 species 506individuals & 21species 319 individuals & 21 species 288 individuals & 21species 363individuals \\
\hline \multicolumn{2}{|c|}{ Total } & 91species & 100species & 84 species & 76species & 71 species & 61 species \\
\hline
\end{tabular}

$\mathrm{N}=$ Naturalized species; $\mathrm{E}=$ endemic species; $\mathrm{R}=$ rare species; * endangered wildlife class II; ** National monument. 
favorable. For rare species, frogbit and Iris ensata were observed from all target wetlands and Euryale ferox Salisbury which was level 2 endangered wild plant was observed from Jungyang wetland, Hwapo wetland, Daepyeong wetland and Jilnal wetland, showing a high conservation value of these wetlands.

Since wild birds, amphibians, dragonflies tended to rely on the wetland system that supported food and spawning (Stewart, 1996) and damage to wetlands led to the reduction of spawning sites, causing the reduction of population of species relying on wetlands (Bellrose and Trudeau, 1988), it was judged that the number of wild animal species was appropriate as an index. For mammal, 3 species from Jungyang wetland, 1 species from Bacsil wetland, 2 species from Hwapo wetland, 2 species from Samrangjin wetland, 4 species from Daepyeong wetland and 1 species from Jilnal wetland were observed, and a wildcat which was level 2 endangered wild animal appeared except for Jilnal wetland. For wild birds, 32 species and 508 individuals from Jungyang wetland, 30 species and 512 individuals from Samrangiin wetland, 27 species and 748 individuals from Bacsil wetland, 27 species and 207 individuals from Daepyeong wetland, 26 species and 965 individuals from Hwapo wetland and 16 species and 334 individuals from Jilnal wetland were observed in order, and Hwapo wetland showed less number of species in comparison to its area. For amphibians and reptiles, 8 species from Jungyang wetland, 7 species from Bacsil wetland, 3 species from Hwapo wetland, 4 species from Samrangjin wetland, 2 species from Daepyeong wetland and 2 species from Jilnal wetland appeared, showing a high possibility for potential habitat in Jungyang wetland, and Korean Golden Frog which was level 2 endangered wild animal appeared in Jungyang wetland and Bacsil wetland, showing a high conservation value. To sum up, the number of wild animal species appeared was 100 species from Bacsil wetland and 91 species from Jungyang wetland, showing the largest number of wild animal species, followed by 84 species from Hwapo wetland, 76 species from Samrangjin wetland and 71 species from Daepyeong wetland, and 61 species appeared from Jilnal wetland, showing the lowest number of species.

\section{2) Area of wetlands and internal naturalness}

Since ecological healthiness could be judged by the landscape context and size (Faber-Langendoen et al., 2012), it was considered that the diversity and healthiness of biological habitat functions could be judged by comparing the broadness and narrowness of wetland. The area was larger in order of Hwapo wetland (2,708,539.16 $\left.\mathrm{m}^{2}\right)$, Jungyang wetland (511,157.62 $\mathrm{m}^{2}$ ), Samrangjin wetland $\left(363,956.87 \mathrm{~m}^{2}\right)$, Bacsil wetland $\left(287,764.15 \mathrm{~m}^{2}\right)$, Jilnal wetland $\left(178,725.33 \mathrm{~m}^{2}\right)$ and Daepyeong wetland $\left(98,195.00 \mathrm{~m}^{2}\right)$, and the Hwapo wetland had the highest potential of biological diversity according to the area size.

Meanwhile, vegetation provides information regarding the terrestrialization progress and dominant vegetation contributes greatly to the classification of wetland type (Amoros et al., 2000; Bedford et al., 1999), so the naturalness evaluation of wetlands based on large aquatic plants and marsh plants is appropriate. Also, the composition of plant community can be considered as a representative index to distinguish the function in the aspect that plant diversity leads the diversity of wildlife species (Balcombe et al., 2005). In order to judge the naturalness based on the growth characteristics of plants, the area where vegetation was distributed was calculated separately into the moisture type for Phragmites communis, Zizania latifolia and Salix koreensis, the arid type for Miscanthus sinensis and Artemisia princeps and naturalized species for Humulus japonicus and Sicyos angulatus based on the investigation and analysis data of existing vegetation and land coverage status. Table 4 is the comparison of area and moisture type vegetation distributed within the wetlands, and the area and ratio of moisture type wood and plants were $30.46 \%$ and $155,689.01$ $\mathrm{m}^{2}$ of Jungyang wetland, $32.75 \%$ and $94,231.35 \mathrm{~m}^{2}$ of Bacsil wetland, $50.91 \%$ and $1,378,815.50 \mathrm{~m}^{2}$ of Hwapo wetland, $45.51 \%$ and $165,640.93 \mathrm{~m}^{2}$ of Samrangjin wetland, $28.31 \%$ and $27,793.97 \mathrm{~m}^{2}$ of Daepyeong wetland and $69.43 \%$ and $124,085.33 \mathrm{~m}^{2}$ of Jilnal wetland respectively. For the whole area, Hwapo wetland had the largest area, followed by Samrangin wetland and Jungyang wetland, but the area ratio of moisture type vegetation was larger in order of Jilnal wetland, Hwapo wetland and Samrangjin wetland. Meanwhile, the damaged area by works accounted for $4.26 \%\left(21,793.91 \mathrm{~m}^{2}\right)$ and $9.01 \%$ $\left(25,921.84 \mathrm{~m}^{2}\right)$ of Jungyang wetland and Bacsil wetland located in Hapcheon-gun respectively, showing a relatively low value. 
Table 4. The area and ratio of actual vegetation types within inland wetland.

\begin{tabular}{|c|c|c|c|c|c|c|}
\hline \multirow{2}{*}{ Classification } & \multicolumn{2}{|c|}{ Jungyang wetland } & \multicolumn{2}{|c|}{ Bacsil wetland } & \multicolumn{2}{|c|}{ Hwapo wetland } \\
\hline & Area $\left(\mathrm{m}^{2}\right)$ & Ratio (\%) & Area $\left(\mathrm{m}^{2}\right)$ & Ratio (\%) & Area $\left(\mathrm{m}^{2}\right)$ & Ratio (\%) \\
\hline Arid type woody plants & $49,025.91$ & 9.59 & $3,538.79$ & 1.23 & $44,603.08$ & 1.65 \\
\hline Arid type grassland & $23,099.32$ & 4.52 & $7,564.84$ & 2.63 & $171,823.46$ & 6.34 \\
\hline Shrub & $15,336.99$ & 3.00 & $2,514.02$ & 0.87 & - & - \\
\hline Naturalized grassland & $21,066.18$ & 4.12 & - & - & - & - \\
\hline Farmland & $3,280.19$ & 0.64 & $13,861.62$ & 4.82 & $740,850.99$ & 27.35 \\
\hline Farmland (artificial facilities) & - & - & - & - & $22,856.04$ & 0.84 \\
\hline Moisture type wood plants & $42,451.98$ & 8.31 & $17,200.11$ & 5.98 & $835,794.89$ & 30.86 \\
\hline Moisture type grassland & $113,237.03$ & 22.15 & $77,031.24$ & 26.77 & $543,020.61$ & 20.05 \\
\hline Damaged area within wetland & $21,793.91$ & 4.26 & $25,921.84$ & 9.01 & - & - \\
\hline Water surface and channel & $89,488.00$ & 17.51 & $131,422.97$ & 45.67 & $247,073.20$ & 9.12 \\
\hline Urbanized area & $132,378.11$ & 25.90 & $8,708.72$ & 3.03 & $102,516.90$ & 3.78 \\
\hline Total & $511,157.62$ & 100.00 & $287,764.15$ & 100.00 & $2,708,539.16$ & 100.00 \\
\hline \multirow{2}{*}{ Classification } & \multicolumn{2}{|c|}{ Samrangjin wetland } & \multicolumn{2}{|c|}{ Daepyeong wetland } & \multicolumn{2}{|c|}{ Jilnal wetland } \\
\hline & Area $\left(m^{2}\right)$ & Ratio (\%) & $\operatorname{Area}\left(\mathrm{m}^{2}\right)$ & Ratio (\%) & Area $\left(\mathrm{m}^{2}\right)$ & Ratio (\%) \\
\hline Arid type woody plants & $20,825.08$ & 5.72 & $1,261.90$ & 1.29 & - & - \\
\hline Arid type grassland & - & - & - & - & - & - \\
\hline Shrub & $13,995.65$ & 3.85 & $2,504.03$ & 2.55 & $1,381.68$ & 0.77 \\
\hline Naturalized grassland & $28,122.30$ & 7.73 & $2,206.77$ & 2.25 & - & - \\
\hline Farmland & $57,478.45$ & 15.79 & $1,361.07$ & 1.39 & $2,852.10$ & 1.60 \\
\hline Farmland (artificial facilities) & - & - & - & - & - & - \\
\hline Moisture type wood plants & $55,389.92$ & 15.22 & $1,106.62$ & 1.13 & $24,075.31$ & 13.47 \\
\hline Moisture type grassland & $110,251.01$ & 30.29 & $26,687.35$ & 27.18 & $100,010.02$ & 55.96 \\
\hline Damaged area within wetland & - & - & - & - & - & - \\
\hline Water surface and channel & $71,057.97$ & 19.52 & $62,459.37$ & 63.61 & $50,406.22$ & 28.20 \\
\hline Urbanized area & $6,836.48$ & 1.88 & 607.90 & 0.62 & - & - \\
\hline Total & $363,956.87$ & 100.00 & $98,195.00$ & 100.00 & $178,725.33$ & 100.00 \\
\hline
\end{tabular}

\section{3) Distribution status of pollution sources}

Generally, it is advisable to manage wetlands or carry out the evaluation based on data related to internal and external land use, water quality and topography (Jones et al., 2009). The ecological process may vary according to a change in the surrounding land use type (Amoros et al., 2000) and the area of peripheral developed land is useful for evaluating the healthiness of wetlands (U.S. Geological Survey, 1996), so it is necessary to identify pollution and damage factors distributed over inside and outside the wetlands. Table 5 shows the classification based on the land coverage investigation data of each wetland by considering the inflow possibility of pollutants. As a result of analyzing the distribution of pollutant by distance targeting an area around $50 \mathrm{~m}$ from the wetlands, the area ratio of stables, urbanized areas and roads causing serious significant pollution account for $63.36 \%$ of Jungyang wetland, $0.43 \%$ of Bacsil wetland, $41.67 \%$ of Hwapo wetland, $1.19 \%$ of Samrangin wetland, $17.90 \%$ of Daepyeong wetland and $18.94 \%$ of Jilnal wetland, and the potential for pollution was higher in order of Jungyang wetland, Hwapo wetland, Jilnal wetland, Daepyeong wetland, Samrangjin wetland and Bacsil wetland. Meanwhile, the area ratio of potential for pollution by farmland that was non-point pollutant source was $15.87 \%$ of Jungyang wetland, $21.60 \%$ of Bacsil wetland, $34.56 \%$ of Hwapo wetland, $91.77 \%$ 
of Samrangjin wetland, $11.89 \%$ of Daepyeong wetland and $30.25 \%$ of Jilnal wetland, but the potential for pollution by surrounding farmlands was higher in order of Samrangin wetland, Hwapo wetland, Jilnal wetland, Bacsil wetland,
Daepyeong wetland and Jungyang wetland, indicating that Jungyang wetland and Hwapo wetland showed the highest potential for pollution, requiring management.

Table 5. Distribution status of pollution sources around wetlands (within $50 \mathrm{~m}$ from the boundary).

\begin{tabular}{|c|c|c|c|c|c|c|}
\hline \multirow{2}{*}{ Classification } & \multicolumn{2}{|c|}{ Jungyang wetland } & \multicolumn{2}{|c|}{ Bacsil wetland } & \multicolumn{2}{|c|}{ Hwapo wetland } \\
\hline & Area $\left(\mathrm{m}^{2}\right)$ & Ratio (\%) & Area $\left(\mathrm{m}^{2}\right)$ & Ratio (\%) & Area $\left(\mathrm{m}^{2}\right)$ & Ratio (\%) \\
\hline Arid type woody plants & $9,144.31$ & 3.28 & $2,849,504.94$ & 74.13 & $60,765.97$ & 5.97 \\
\hline Moisture type wood plants & $3,702.04$ & 1.33 & $32,558.37$ & 0.85 & 923.36 & 0.09 \\
\hline Naturalized type wood plants & $12,784.26$ & 4.58 & $13,069.03$ & 0.34 & 1.40 & 0.00 \\
\hline Shrub & $4,412.44$ & 1.58 & $52,241.72$ & 1.36 & - & - \\
\hline Water surface and channel & $4,690.08$ & 1.68 & - & - & $145,908.58$ & 14.33 \\
\hline Moisture type grassland & $5,517.87$ & 1.98 & $16,040.29$ & 0.42 & $9,835.55$ & 0.97 \\
\hline Arid type grassland & $12,008.12$ & 4.30 & $27,143.82$ & 0.71 & $24,437.40$ & 2.40 \\
\hline Naturalized type grassland & $5,661.79$ & 2.03 & $6,558.80$ & 0.17 & - & - \\
\hline Agriculture land & $44,261.21$ & 15.87 & $830,478.85$ & 21.60 & $351,893.22$ & 34.56 \\
\hline Housing & 865.29 & 0.31 & $16,340.19$ & 0.43 & $10,030.69$ & 0.99 \\
\hline Public building & - & - & - & - & $15,194.35$ & 1.49 \\
\hline Urban maintenance facilities & $3,771.83$ & 1.35 & - & - & - & - \\
\hline Commercial and industrial land & $57,597.67$ & 20.65 & - & - & $122,778.30$ & 12.06 \\
\hline Barn & $2,100.31$ & 0.75 & - & - & $5,444.74$ & 0.53 \\
\hline Road & $79,036.10$ & 28.33 & - & - & $54,193.37$ & 5.32 \\
\hline Bare land & $33,382.91$ & 11.97 & - & - & $216,678.93$ & 21.28 \\
\hline other urbanized area & - & - & - & - & - & - \\
\hline Total & $278,936.23$ & 100.00 & $3,843,936.01$ & 100.00 & $1,018,085.86$ & 100.00 \\
\hline \multirow{2}{*}{ Classification } & \multicolumn{2}{|c|}{ Samrangjin wetland } & \multicolumn{2}{|c|}{ Daepyeong wetland } & \multicolumn{2}{|c|}{ Jilnal wetland } \\
\hline & $\operatorname{Area}\left(\mathrm{m}^{2}\right)$ & Ratio (\%) & Area $\left(\mathrm{m}^{2}\right)$ & Ratio (\%) & Area $\left(\mathrm{m}^{2}\right)$ & Ratio (\%) \\
\hline Arid type woody plants & $4,530.52$ & 0.66 & $562,752.63$ & 62.17 & $459,297.49$ & 46.86 \\
\hline Moisture type wood plants & $1,070.89$ & 0.16 & 749.96 & 0.08 & - & - \\
\hline Naturalized type wood plants & - & - & $40,926.68$ & 4.52 & $13,429.27$ & 1.37 \\
\hline Shrub & - & - & - & - & $13,411.04$ & 1.37 \\
\hline Water surface and channel & $16,066.09$ & 2.33 & 721.24 & 0.08 & $3,205.26$ & 0.33 \\
\hline Moisture type grassland & $18,073.26$ & 2.62 & - & - & - & - \\
\hline Arid type grassland & $1,458.64$ & 0.16 & $1,458.64$ & 0.16 & $3,669.35$ & 0.37 \\
\hline Naturalized type grassland & $8,842.23$ & 1.28 & $28,953.84$ & 3.20 & $4,908.82$ & 0.50 \\
\hline Agriculture land & $633,515.23$ & 91.77 & $107,610.91$ & 11.89 & $296,471.72$ & 30.25 \\
\hline Housing & - & - & $121,728.01$ & 13.45 & $2,336.02$ & 0.24 \\
\hline Public building & - & - & - & - & - & - \\
\hline Urban maintenance facilities & - & - & 512.18 & 0.06 & 525.31 & 0.05 \\
\hline Commercial and industrial land & - & - & $4,803.58$ & 0.53 & $112,363.00$ & 11.46 \\
\hline Barn & - & - & - & - & $23,081.89$ & 2.36 \\
\hline Road & - & - & $32,782.28$ & 3.62 & $43,366.59$ & 4.42 \\
\hline Bare land & $8,197.35$ & 1.19 & - & - & $4,002.22$ & 0.41 \\
\hline other urbanized area & - & - & $2,182.74$ & 0.24 & - & - \\
\hline Total & $690,295.56$ & 100.00 & $905,182.68$ & 100.00 & $980,067.98$ & 100.00 \\
\hline
\end{tabular}




\section{Evaluation index and scoring standard}

For selecting the evaluation index, only physical and biological characteristics were considered by considering the fact that a method that could evaluate the physical structure, chemical properties of water, and biological properties comprehensively was proposed commonly (Adamus et al., 1987; Brinson, 1993; Smith et al., 1995) the opinions of Kent et al. (1992), Turner et al. (1993), Hruby et al. (1999) asserting that the measurement simplicity, availability, cost efficiency as well as ease of information improvement needed to be available for selecting the evaluation index. The ecological integrity (Mollard et al., 2013) for physical characteristics and the disturbance level (Johnston et al., 2009) and suitability as biological habitats (Stewart, 1996) for biological properties were evaluated in order to reflect qualitative aspects. For detailed evaluation items of each index, the landscape unit diversity and wildlife inhabit diversity for biological diversity and the naturalness of biotope and basin ecosystem for the naturalness were selected as detailed index. The distribution and inhabit of major plant species for rarity were evaluated and the distribution of pollutant by distance and degree of internal damage for potential for damage were evaluated. The evaluation details are as shown in
Table 6. The method of Kim (2005) classifying the evaluation index for each evaluation item into the fixed index that remained unchanged for the ecosystem structure and theoretical target area and variable index comparable for each target area or purpose of study was applied. The comparative index was the concept to consider the characteristics of target area and apply weight, but objective and quantitative precedent studies regarding the evaluation index such as landscape unit diversity, wildlife inhabit diversity, naturalness of biotope and naturalness of basin ecosystem were not carried out previously, so only 6 inland wetlands included in the wetlands road map among the inland wetlands distributed in Gyeongsangnam-do Province were compared in this study. The fixed index applicable only to the target area of this study included 2 major animal and plant distributions among rarity and the comparative index could be applicable, and 5-point scale based on the maximum value was applied for calculating the comparative index evaluation score.

Table 7 shows the criteria of evaluation index and grading for each item. The landscape unit diversity among the biological diversity was a comparative index and it was graded based on the maximum number of biotope types after investigating the

Table 6. Standard of evaluation items and contents.

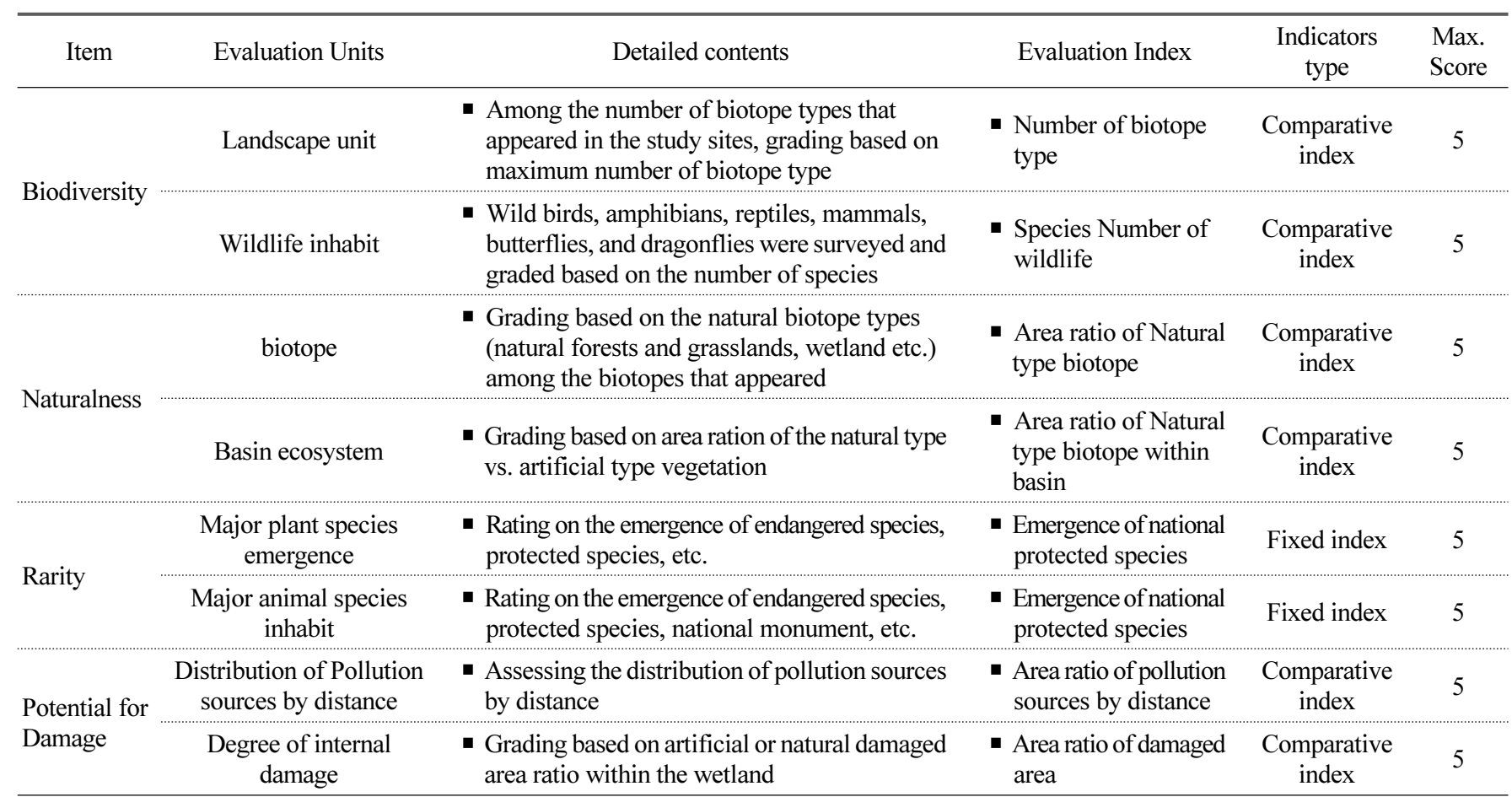


biotope types appeared from the target areas for study. Along all target areas, the largest number of biotope types (10 types) appeared from Jungyang wetland, so the 10 biotope types (maximum value) were classified into 5 levels including 5 or less types, 6 types, $7 \sim 8$ types, 9 types and 10 or more types by applying the 5-point scale. For the wildlife inhabit diversity, wild birds, amphibians and mammals appeared in each target area were investigated and graded based on the maximum number of species identified by applying the comparative index. Since the largest number of species (100 species) was observed from Bacsil wetland among the target areas for study, so 100 species (maximum value) were classified into 5 levels including 60 or less species, $61 \sim 70$ species, $71 \sim 80$ species, $81 \sim 90$ species and 91 or more species at the equal interval by applying the 5-point scale. The naturalness of biotope among naturalness was a comparative index so that the area ratio of natural type biotope was applied, and it was classified into 5 levels based on $60 \%$ and $90 \%$ as a result of calculating the area ratio of natural forest, indigenous grassland, wetland and water system corresponding to the natural type. The naturalness of basin ecosystem was a comparative index so that the area ratio of natural vegetation emergence in the basin was applied, and the area ratio of natural forest, indigenous grassland, wetland and water system corresponding to natural type biotope among biotope types was calculated and classified into 5 levels based on $10 \%$ and $70 \%$.
For major rare animal species inhabits, the emergence of endangered wild animals facing the crisis of extinction due to the deterioration of habitat environment or population declines, natural monuments that were indigenous species in Korea, and protected wild animals and plats was utilized ad the rating standards. Only wild animals among nationally protected species appeared, so the evaluation was carried out separately for the area with emergence of endangered wild animals (5 points), area with emergence of protected wild animals, natural monument and rare species ( 3 points), area with no emergence of nationally protected species ( 1 point) legally according to the extinction and protection level, and the evaluation score was calculated preferentially when a species with a high protection level among wild animals appeared. Meanwhile, the area of land developed near wetland is a useful index for evaluating the healthiness of wetland (U.S. Geological Survey, 1996). Therefore, the area ratio of pollution sources by distance for damage potential and the ratio of damaged area inside wetland for the degree of internal damage was calculated and a score was given by classifying the minimum value and the maximum value at the equal interval.

\section{Evaluation of conservation priority}

Table 8 shows the scoring result for determining the conservation priority of wetlands by referring to the criteria of evaluation index and grading (Table 7). Jungyang wetland had

Table 7. Criteria of evaluation index and order of priority

\begin{tabular}{|c|c|c|c|c|c|c|c|c|c|}
\hline \multicolumn{2}{|c|}{ Classification } & \multicolumn{2}{|c|}{ Biodiversity } & \multicolumn{2}{|c|}{ Naturalness } & \multicolumn{2}{|c|}{ Rarity } & \multicolumn{2}{|c|}{ Potential for damage } \\
\hline \multicolumn{2}{|l|}{ Item } & $\begin{array}{l}\text { Landscape } \\
\text { units }\end{array}$ & $\begin{array}{l}\text { Wildlife } \\
\text { inhabit }\end{array}$ & biotope & $\begin{array}{c}\text { Basin } \\
\text { ecosystem }\end{array}$ & $\begin{array}{c}\text { Major plant species } \\
\text { emergence }\end{array}$ & $\begin{array}{l}\text { Major animal } \\
\text { species inhabit }\end{array}$ & $\begin{array}{c}\text { Distribution of } \\
\text { Pollutant by } \\
\text { distance }\end{array}$ & $\begin{array}{l}\text { Degree of } \\
\text { internal } \\
\text { damage }\end{array}$ \\
\hline \multicolumn{2}{|l|}{$\begin{array}{l}\text { Indicators } \\
\text { type }\end{array}$} & $\begin{array}{l}\text { Comparative } \\
\text { index }\end{array}$ & $\begin{array}{l}\text { Comparative } \\
\text { index }\end{array}$ & $\begin{array}{l}\text { Comparative } \\
\text { index }\end{array}$ & $\begin{array}{l}\text { Comparative } \\
\text { index }\end{array}$ & Fixed index & Fixed index & $\begin{array}{l}\text { Comparative } \\
\text { index }\end{array}$ & $\begin{array}{l}\text { Comparative } \\
\text { index }\end{array}$ \\
\hline \multicolumn{2}{|l|}{ Standard } & $\begin{array}{l}\text { Number of } \\
\text { biotope } \\
\text { type }\end{array}$ & $\begin{array}{l}\text { Species } \\
\text { Number of } \\
\text { wildlife }\end{array}$ & $\begin{array}{l}\text { Area ratio of } \\
\text { Natural type } \\
\text { biotope }\end{array}$ & $\begin{array}{l}\text { Area ratio of } \\
\text { Natural type } \\
\text { biotope within } \\
\text { basin }\end{array}$ & $\begin{array}{l}\text { Emergence of } \\
\text { national } \\
\text { protected } \\
\text { species }\end{array}$ & $\begin{array}{l}\text { Emergence of } \\
\text { national } \\
\text { protected } \\
\text { species }\end{array}$ & $\begin{array}{l}\text { Area ratio of } \\
\text { pollution } \\
\text { sources by } \\
\text { distance }\end{array}$ & $\begin{array}{c}\text { Area ratio of } \\
\text { damaged } \\
\text { area }\end{array}$ \\
\hline \multirow{5}{*}{$\begin{array}{l}\text { Grading } \\
\text { criteria }\end{array}$} & 5 & More than 10 & $\begin{array}{l}\text { More than } 91 \\
\text { species }\end{array}$ & $\begin{array}{c}\text { More than } \\
90 \%\end{array}$ & $\begin{array}{c}\text { More than } \\
70 \%\end{array}$ & $\begin{array}{l}\text { Endangered wild } \\
\text { plants }\end{array}$ & $\begin{array}{l}\text { Endangered wild } \\
\text { animals }\end{array}$ & $\begin{array}{c}\text { Less than } \\
20 \%\end{array}$ & $\begin{array}{c}\text { Less than } \\
10 \%\end{array}$ \\
\hline & 4 & 9 & 81 90species & $80 \sim 90 \%$ & $50 \sim 70 \%$ & - & - & $20 \sim 40 \%$ & $10 \sim 15 \%$ \\
\hline & 3 & $7 \sim 8$ & 71 80species & $70 \sim 80 \%$ & $30 \sim 50 \%$ & $\begin{array}{l}\text { Protected, rarity, } \\
\text { or national } \\
\text { monument }\end{array}$ & $\begin{array}{l}\text { Protected } \\
\text { or national } \\
\text { monument }\end{array}$ & $40 \sim 60 \%$ & $15 \sim 20 \%$ \\
\hline & 2 & 6 & 61 70species & $60 \sim 70 \%$ & $10 \sim 30 \%$ & - & - & $60 \sim 80 \%$ & $20 \sim 25 \%$ \\
\hline & 1 & Less than 5 & $\begin{array}{l}\text { Less than } \\
60 \text { species }\end{array}$ & $\begin{array}{l}\text { Less than } \\
60 \%\end{array}$ & $\begin{array}{l}\text { Less than } \\
10 \%\end{array}$ & $\begin{array}{l}\text { No national level } \\
\text { protected species }\end{array}$ & $\begin{array}{l}\text { No national level } \\
\text { protected species }\end{array}$ & $\begin{array}{l}\text { More than } \\
80 \%\end{array}$ & $\begin{array}{l}\text { More than } \\
25 \%\end{array}$ \\
\hline
\end{tabular}


10 biotope types and 91 wild animal species including 3 natural monument species and 5 level II endangered wild animal species and 2 rare plant species and 1 legally protected plant species for plant species. For the damages, the area ratio of pollution sources by distance was $79.23 \%$ and the area ratio of damaged area was $34.92 \%$, showing a high risk, so the damages were assessed at 26 points. Bacsil wetland had 9 biotope types and 100 wild animal species including 3 natural monuments, 2 level II endangered wild animal species and 3 rare plant species. For the damages, the area ratio of pollution sources by distance was $21.03 \%$ and the area ratio of damaged area was $16.86 \%$, showing an intermediate risk, so the damages were assessed at 32 points. Hwapo wetland had 8 biotope types and 84 wild animal species including 2 natural monument species and 2 level II Endangered wild animal species and 2 rare plant species and 1 legally protected plant species for plant species. For the damages, the area ratio of pollution sources by distance was $76.23 \%$ and the area ratio of damaged area was $31.97 \%$, showing a high potential for damage, so the damages were assessed at 23 points. Samrangjin wetland had 8 biotope types and 76 wild animal species including 1 natural monument species and 1 level II Endangered wild animal species and 2 rare plant species for plant species. For the damages, the area ratio of pollution sources by distance was $92.96 \%$ and the area ratio of damaged area was $17.67 \%$, showing an intermediate potential for damage, so the damages were assessed at 21 points. Daepyeong wetland had 8 biotope types and 71 wild animal species including 1 natural monument species and 2 level II Endangered wild animal species and 3 rare plant species and 1 legally protected plant species for plant species. For the damages, the area ratio of pollution sources by distance was $29.79 \%$ and the area ratio of damaged area was $4.26 \%$, showing proper conservation status, so the damages were assessed at 34 points. Jilnal wetland had 5 biotope types and 61 wild animal species including 1 natural monument species and 2 rare plant species and 1 legally protected plant species for plant species. For the damages, the area ratio of pollution sources by distance was high as $49.19 \%$ but the area ratio of damaged area was $1.60 \%$, showing proper conservation status, so the damages were assessed at 27 points.

As a result of evaluation, Hwapo wetland had the largest area so that it was expected that the biological diversity would be high, but the possibility of damage in the basin zone was high and its naturalness was low in comparison to its area, so the final score was low as 23 points. In case of Samrangjin wetland, the area of damaged land such as vinyl greenhouse was also large so that the number of inhabiting species and individuals was less, so the final score was low as 21 points. Generally, a decrease in the population of species depending on wetlands is caused by the reduction of habitat such as area reduction and internal damage (Bellrose and Trudeau, 1988). In case of Hwapo wetland and Samrangjin wetland, wide area of pollution source inside and outside of those wetlands led to a decrease in the number of wild animal and plant species so that the final score was low. On the other hand, Daepyeong wetland and Bacsil wetland that had small area but were

Table 8. The result of evaluation for conservation and management priority in inland wetland.

\begin{tabular}{|c|c|c|c|c|c|c|c|c|c|c|c|c|c|}
\hline & \multirow{2}{*}{ Criteria items } & \multicolumn{2}{|c|}{ Jungyang wetland } & \multicolumn{2}{|c|}{ Bacsil wetland } & \multicolumn{2}{|c|}{ Hwapo wetland } & \multicolumn{2}{|c|}{ Samrangjin wetland } & \multicolumn{2}{|c|}{ Daepyeong wetland } & \multicolumn{2}{|c|}{ Jilnal wetland } \\
\hline & & Status & Score & Status & Score & Status & Score & Status & Score & Status & Score & Status & Score \\
\hline \multirow{2}{*}{ Biodiversity } & Landscape unit (No.) & 10 & 5 & 9 & 4 & 8 & 3 & 8 & 3 & 8 & 3 & 5 & 1 \\
\hline & Wildlife inhabit (No. of species) & 91 & 5 & 100 & 5 & 84 & 4 & 76 & 3 & 71 & 3 & 61 & 2 \\
\hline \multirow{2}{*}{ Naturalness } & biotope (\%) & 47.97 & 1 & 78.42 & 3 & 60.03 & 1 & 65.03 & 2 & 91.92 & 5 & 97.63 & 5 \\
\hline & Basin ecosystem (\%) & 14.15 & 2 & 77.47 & 5 & 23.76 & 2 & 5.93 & 1 & 62.49 & 4 & 48.93 & 3 \\
\hline \multirow{2}{*}{ Rarity } & $\begin{array}{l}\text { Major plant species emergence } \\
\text { (No. of species) }\end{array}$ & $\mathrm{R}(2) / \mathrm{E}(1)$ & 5 & $\mathrm{R}(1)$ & 3 & $\mathrm{R}(2) / \mathrm{E}(1)$ & 5 & $\mathrm{R}(1)$ & 3 & $\mathrm{R}(3) / \mathrm{E}(1)$ & 5 & $\mathrm{R}(2) / \mathrm{E}(1)$ & 5 \\
\hline & $\begin{array}{l}\text { Major animal species inhabit } \\
\text { (No. of species) }\end{array}$ & $\mathrm{N}(3) / \mathrm{E}(5)$ & 5 & $\mathrm{~N}(3) / \mathrm{E}(2)$ & 5 & $\mathrm{~N}(2) / \mathrm{E}(2)$ & 5 & $\mathrm{~N}(1) / \mathrm{E}(1)$ & 5 & $\mathrm{~N}(1) / \mathrm{E}(2)$ & 5 & $\mathrm{~N}(1)$ & 3 \\
\hline \multirow{2}{*}{$\begin{array}{l}\text { Potential for } \\
\text { damage }\end{array}$} & $\begin{array}{c}\text { Distribution of Pollutant by } \\
\text { distance }(\%)\end{array}$ & 79.23 & 2 & 21.03 & 4 & 76.23 & 2 & 92.96 & 1 & 29.79 & 4 & 49.19 & 3 \\
\hline & Degree of internal damage (\%) & 34.92 & 1 & 16.86 & 3 & 31.97 & 1 & 17.67 & 3 & 4.26 & 5 & 1.60 & 5 \\
\hline & Total & \multicolumn{2}{|c|}{26} & \multicolumn{2}{|l|}{32} & \multicolumn{2}{|l|}{23} & \multicolumn{2}{|l|}{21} & \multicolumn{2}{|l|}{34} & \multicolumn{2}{|c|}{27} \\
\hline
\end{tabular}

$\mathrm{R}=$ Rare species; $\mathrm{N}=$ National monument; $\mathrm{E}=$ Endangered species. 
surrounded by forests, preventing people from accessing and the biological diversity was high accordingly showed a high conservation value as 34 points and 32 points respectively. Disturbance was rapid physical environment change for ecosystem, community and population structure and the recovery of function was decided depending on the resistance and regenerative capacity of system (Pickett and White, 1985), so it is essential to maintain wetlands with high biological diversity intactly. As a result, inland wetlands were mostly damaged by human interference such as reclamation, works and construction of a plant in the periphery areas, so it was judged that prohibiting the development in the periphery areas and preventing the inflow of sewage and wastewater from roads, industrial areas and residential areas was the best plan for protection in the present conditions. Also, it was considered that it would be advisable to purchase and restore farmlands and urbanized areas directly bordering wetlands into wetlands or develop such lands into treatment wetlands that purified incoming pollution sources from surrounding areas. Meanwhile, the ecosystem conservation is an effort to manage environmental change ratio to maintain the supply of products and services for a long period of time (Turner et al., 1993), so it is necessary to manage such change ratio to enable the performance of support service functions such as the supply of food and water, carbon emission reduction, adjustment of water quality, biological diversity and material cycling in terms of ecosystem service (Morris and Camino, 2011). Understanding of functions, granting time to the system and the allowance of self-design are necessary for correct conservation and management of wetlands and it is necessary to approach the conservation and management in terms of understanding the whole with proper time and space scale, that is a common approach of researchers for the management.

\section{Conclusion}

Wetlands have been recognized as useless lands for a long period of time and such lands have been evaluated as the target for development, so the loss of a wide area through landfill occurs around the world. So, there is a need to present the direction of wetlands policies correctly along with the improvement of awareness. Therefore, the evaluation of wetlands is highly important not only for evaluating the functions of wetlands but also for selecting the conservation or restoration priorities. The opinion prevails in the country that it is difficult to carry out the spatial range and quantitative evaluation using the RAM (Rapid Appraisal Wetland Condition Index) method used in the country for evaluating the functions of wetlands (Lee et al., 2014). Therefore, the evaluation index and conservation and management priorities were selected based on the investigation and analysis result of environmental and ecological characteristics and potential for damage that could be collected from the field in this study. The plants ecosystem corresponding to the basis of ecosystem was classified by considering the layer structure and natural characteristics of dominant species based on the existing vegetation and land coverage for the evaluation unit. Only the physical and biological properties that could be acquired through the field investigation were considered since the measurement simplicity, availability, cost efficiency as well as ease of information improvement needed to be considered for index to compare the ecological value of wetlands and impact area. The biological diversity (landscape unit diversity, wildlife inhabit diversity), naturalness (naturalness of biotope, naturalness of basin ecosystem), rarity (major plant species emergence, major animal species inhabit), potential for damage (distribution of pollution sources by distance, degree of internal damage) were selected as the index in order to reflect qualitative aspects such as ecological integrity for the physical characteristics and disturbance level and suitability as biological habitats for the biological properties. The variable index applying weight by considering the characteristics of target area included landscape unit diversity, wildlife inhabit diversity, naturalness of biotope and naturalness of basin ecosystem and the fixed index that remained unchanged for the ecosystem structure and theoretical target area included 2 major animal and plant distributions among rarity.

As a result of evaluating the conservation priorities, Hwapo wetland ( 23 points) and Samrangjin wetland ( 21 points) where the area was large but vinyl greenhouses and bare grounds were distributed, showing high potential for damage and less number of inhabiting species and individuals, had a low conservation value. On the other hand, Daepyeong wetland (34 points) and Bacsil wetland (32 points) where the area was not large but whooper swans, anser fabalis and euryale ferox 
salisbury that were endangered wildlife appeared, showing good biological diversity, had a high conservation value. When simple evaluation (RAM) or ecosystem service was applied for wetlands evaluation, the priority order of importance regarding the functions of wetlands including the flood prevention, water purification, aesthetic function, water supply source retaining function and underground water storage function was drawn but the factors influencing such functions could not be presented. In other words, it was identified that it was impossible to confirm specific details of animal and plant ecosystems that needed to be considered practically for the conservation and restoration of unique wetland functions. The habitat disturbance such as decrease in area of wetlands or internal damage presented as the result of this study causes a rapid change in biological and physical environments such as ecosystem, community and population structure. On the other hand, the functional recovery of wetland ecosystem is decided depending on the resistance and reproducibility of the system, priority should be given to the maintenance of wetlands with high biological diversity intactly over the restoration. Inland wetlands were mostly damaged by human interference such as reclamation, works and construction of a plant in the periphery areas, so it was judged that prohibiting the development in the periphery areas and preventing the inflow of sewage and wastewater from roads, industrial areas and residential areas was the best plan for conservation in the present conditions. Also, it was considered that it would be advisable to purchase and restore farmlands and urbanized areas directly bordering wetlands into wetlands or develop such lands into treatment wetlands that purified incoming pollution sources from surrounding areas.

Understanding of wetlands functions, granting time to the system and the allowance of self-design are necessary for correct conservation and management, and it is necessary to approach the conservation and management in terms of understanding the whole with proper time and space scale, that is a common approach of researchers for the management. However, a follow-up study to secure objectivity such as expert delphi survey for selecting the evaluation index would be necessary in future in order to compare the ecological value of wetlands scattered around the whole country relatively or absolutely.

\section{Reference}

Adamus, P.R., Clairain, E.J., Jr., Smith, R.D., and Young, R.E. 1987. Wetland evaluation technique (WET). Volume 2. Methodology. Operational draft technical report FHWA-IP-88-029. USA: US Army Engineers Waterways Experiment Station.

Amoros, C., G. Bornette, and C.P. Henry. 2000. A vegetation-based method for ecological diagnosis of Riverine wetlands. Environ. Manag. 25(2):211-227. DOI: 10.1007/s002679910017

Balcombe, C.K., J.T. Anderson, R.H. Fortney, J.S. Rentch, W.N. Grafton, and W.S. Kordek. 2005. A comparison of plant communities in mitigation and reference wetlands in the midappalachians. Wetlands, 25(1):130-142. DOI: 10.1672/02775212(2005)025[0130:ACOPCI]2.0.CO;2

Bedford, B.L., M.R. Walbridge, and A. Aldous. 1999. Patterns in nutrient availability and plant diversity of temperate North American wetlands. Ecology 80(7):2151-2169. DOI: 10.1890/ 0012-9658(1999)080[2151:PINAAP]2.0.CO;2

Bellrose, F.C. and N.M. Trudeau. 1988. Wetlands and their relationship to migrating and winter populations of waterfowl. In The ecology and management of wetlands (pp. 183-194). Portland, USA: Springer US.

Berhanu, G. 2012. Valuation of Choke Mountain Range wetland ecosystem, East Gojjam, Amhara Region, Ethiopia: Application of choice experiment valuation method. Addis Ababa University. Department of Economics. Degree of Masters of Science in Economics (International Economics).

Bibby, C.J., N.D. Burgess, D.A. Hill and S.H. Mustoe. 2000. Bird census technique. London, UK: Elsevier Ltd.

Breckenridge, R.P., W.G. Kepner, and D.A. Mouat. 1995. A process for selecting indicators for monitoring conditions of rangeland health. Environ. Monit. Assess. 36(1):45-60. DOI: 10.1007/ BF00546984

Brinson, M.M. 1993. Hydrogeomorphic classification for wetlands. Wetlands Research Program Technical Report WRP-DE-4. Retrieved from http://www.dtic.mil/get-tr-doc/pdf?AD=ADA270053

Buijse, A.D., F. Klijn, R.S.E.W. Leuven, H. Middelkoop, F. Schiemer, J.H. Thorp, and H.P. Wolfert. 2005. Rehabilitation of large rivers: references, achievements and integration into river management. Arch. fur Hydrobiol. Suppl. 155(1-4):715-738.

Cowardin, L.M., V. Carter, F.C. Golet, and E.T. LaRoe. 1979. Classification of wetlands and deepwater habitats of the United States. US Department of the Interior, US Fish and Wildlife Service. Retrieved from http://www.online-pdh.com/engcourses/ file.php/51/COW_SG.pdf

Dugan, P. 1993. Wetlands in Danger: a World conservation atlas. New York, USA: Oxford University Press.

Ervin, G.N., B.D. Herman, J.T. Bried, and D.C. Holly. 2006. Evaluating non-native species and wetland indicators status as components of wetlands floristic assessment. Wetlands 26(4):1114-1129. DOI: 10.1672/0277-5212(2006)26[1114:ENSAWI]2.0.CO;2

Faber-Langendoen, D., C. Hedge, M. Kost, S. Thomas, L. Smart, R. Smyth, and S. Menard. 2011. Assessment of Wetland Ecosystem 
Condition across Landscape Regions: A Multi-metric Approach. Washington, D.C., USA: NatureServe, Arlington, VA.

Haering, K.C. and J.M. Galbraith. 2010. Literature Review for Development of Maryland Wetland Monitoring Strategy: Review of Evaluation Methods. U.S. Environmental Protection Agency State Wetland Program Development. Retrieved from http:// www.mde.state.md.us/programs/water/WetlandsandWaterway s/DocumentsandInformation/Documents/www.mde.state.md.u s/assets/document/WetlandsWaterways/Review_of_Evaluation Methods_3-30-10\%20FINAL.pdf

Hruby, T. 2001. Testing the basic assumption of the hydrogeomorphic approach to assessing wetland functions. Environ. Manag. 27(5): 749-761. DOI: $10.1007 / \mathrm{s} 002670010185$

Hruby, T., T. Granger, K. Bruner, S. Cooke, K. Dublanica, R. Gersib, and E. Teachout. 1999. Methods for assessing wetland functions. Volume I : Riverine and depressional wetlands in the Lowlands of Western Washington. Ecology Publication, 99-115. Retrieved from https://test-fortress.wa.gov/ecy/publications/publications/ 99115.pdf

Jensen, J. R., S. Narumalani, O. Weatherbee, and H.E. Mackey. 1993. Measurement of Seasonal and Yearly Cattail and Waterlily Changes Using Multidate SPOT Panchromatic Data. Photogramm. Eng. Remote Sens. 59(4):519-525.

Johnston, C.A., J.B. Zedler, M.G. Tulbure, C.B. Frieswyk, B.L. Bedford, and L. Vaccaro. 2009. A unifying approach for evaluating the condition of wetland distribution of pollutant by distancemmunities and identifying related stressors. Ecol. Appl. 19(7):1739-1757. DOI: 10.1890/08-1290.1

Jones, K., Y. Lanthier, P. van der Voet, E. van Valkengoed, D. Taylor, and D. Fernández-Prieto. 2009. Monitoring and assessment of wetlands using Earth Observation: The GlobWetland project. J. Environ. Manag. 90(7): 2154-2169. DOI: 10.1016/j.jenvman. 2007.07.037

Kang, S.J. 2004. Development and application of a method for rapid wetland assessment considering functions of wetlands in Korea. MS thesis, Ewha Womans Univ. Seoul, Korea.

Kent, D.M., R.J. Reimold, J.M. Kelly, and C.E. Tammi. 1992. Coupling wetlands structure and function: Developing a condition index for wetlands monitoring. In Ecological indicators. pp. 559-570. USA: Springer US.

Kim, J.S. 2005. A study on the ecological alternate thchnique for the prearrangment area of the forest damage in resort development: A case study of oak valley resort in Wolsong-li, Wonju city. MS thesis, Univ. Seoul, Seoul, Korea.

Koeln, G. 1992. How wet is this wetland. Earth Observation Magazine, July/August, 36-39.

Koo, B.H. and K.G. Kim. 2001. A study on the assessment for the functions of inland wetlands using RAM (Rapid Assessment Method). J. Korean Soc. Environ. Restor. Reveg. Technol. 4(3): 38-48.

Kwak, J.I. 2007. Improvement plan of the landuse structure and the green structure for establishment of the wildbirds' habitation base in urban area-a case study of Gangdong-Gu in Seoul-. MS thesis,
Univ. Seoul, Seoul, Korea.

Kwon, S.H. 2013. A study on classifying the inland wetlands by wetland classification systems. MS thesis, Sangmyeong Univ., Seoul, Korea.

Lee, S.D. and S.B. Kim. 2009. Ecological characteristics analysis and management plan of freshwater lake basin-a case study on Duryang reservoir at Sacheon-. J. Korean Inst. Landsc. Archit. 37(1):50-64.

Lee, S.D. 2007. Ecological planning technique for considering biotope evaluation of housing development districts. J. Korean Inst. Landsc. Archit. 34(6):22-38.

Lee, S.D., M.J. Kim, and G.S. Kim. 2015. Vegetational characteristics and management measures of the North-gate Mountainous wetland Mt. Geumjeong. J. Korean Soc. People Plants Environ. 18(4):227-240. DOI: 10.11628/ksppe.2015.18.4.227

Lee, S.J., H.A. Choi, W.K. Lee, J.Y. Lee, S.W. Jeon, and J.S. Kim. 2014. Determining the priority order of wetland functions. J. Environ. Impact Assess. 23(3):197-207. DOI: 10.14249/eia.2014. 23.3.197

Manral, U. and F.A. Khudsar. 2013. Assessment of Wetland Water Quality and Avian Diversity of a Human-Modified Floodplain Wetland on River Yamuna. Not. Sci. Biol. 5(1):25-33.

Mattews, J.W., G. Spyreas, and A.G. Endress. 2009. Trajectories of vegetation-based indicators used to assess wetland restoration progress. Ecol. Appl. 19(8):2093-2107. DOI: 10.1890/08-1371.1

McIntosh. R.P. 1986. The background of ecology: concept and theory. Cambridge: Cambridge University Press.

Minnesota Pollution Control Agency. 2006. A comprehensive wetland assessment, monitoring and mapping strategy for Minnesota. Minnesota Pollution Control Agency and Minnesota Department of Natural Resources, St. Paul, MN. 54 pp. USA.

Mitsch, W.J. and J.G. Gosselink. 2000. Wetlands (3 ${ }^{\text {rd }}$ ed.). John Wiley\&Sons Inc., New York. Retrived from http://onlinelibrary. wiley.com/doi/10.1002/rrr.637/abstract

Mollard, F.P.O., A.L. Foote, M.J. Wilson, V. Crisfield, and S.E. Bayley. 2013. Monitoring and Assessment of Wetland Condition Using Plant Morphologic and Physiologic Indicators. Wetlands 33(5):939-947. DOI: 10.1007/s13157-013-0454-5

Morris, J. and M. Camino. 2011. Economic assessment of freshwater, wetland and floodplain (FWF) ecosystem Services. School of Applied Sciences, Cranfield University, Bedford, MK45 2QP: Uk National Ecosystem Assessment (UK NEA).

Naiman, R. J., Magnuson, D. A., McKnight, and J. A. Stanford. 1995. The freshwater imperative: A research agenda. Washington D. C.: Island press.

National Research Coumcil. 1995. Wetlands: Characteristic and Boundaries. Washington D.C., USA: National Academy press.

Novitzki, R.P. 1994. EMAP-Wetlands-A program for assessing wetland condition. Global Wetlands: Old World and New, Elsevier Science, NY, 691-709.

Novitzki, R.P., R.D. Smith, and J.D. Fretwell. 1996. Wetland functions, values, and assessment. National Summary on Wetland Resources. USGS Water Supply Paper, 2425, 79-86. 
U.S. Geological Survey. 1996. National water summary on wetland resources. United States Geological Survey Water-Supply Paper 2425. Reston, US.

Park, K.H., K.T. Kim, H.G. Gwak, and W.S. Lee. 2007. A Prediction of forest wetland distribution using topographic position index. J. Korean Assoc. Geogr. Inf. Stud. 10(1):194-204.

Parker, S.P. 1984. McGraw-Hill dictionary of scientific and technical terms. New York, USA: McGraw-Hill Book Company.

Pickett, S.T.A. and P.S. White. 1985. The ecology of natural disturbance and patch dynamics. New York. UAS: Academic Press.

Ramsar Convention Secretariat. 2013. The Ramsar Convention Manual: a guide to the Convention on Wetlands (Ramsar, Iran, 1971), 6th ed. Ramsar Convention Secretariat, Gland, Switzerland

Smith, R.D., A. Ammann, C. Bartoldus, and M.M. Brinson. 1995. An approach for assessing wetland functions using hydrogeomorphic classification, reference wetlands, and functional indices. Technical Report No. WES/TR/WRP-DE-9. Vicksburg, USA: U.S. Army Engineers Waterways Experiment Station. Retrieved from http:/ www.dtic.mil/get-tr-doc/pdf?AD=ADA307121

Stewart Jr, R.E. 1996. Wetlands as bird habitat. Judy D. Fretwell, John S. Williams, and Phillip J. Redman (eds.) National Water Summary on Wetland Resources, USGS Water-Supply Paper, 2425, 49-56.

Teferi, E., S. Uhlenbrook, W. Bewket, J. Wenninger, and B. Simane.
2010. The use of remote sensing to quantify wetland loss in the Choke Mountain range, Upper Blue Nile basin, Ethiopia. Hydrol. Earth Syst. Sci. 14(12): 2415-2428. DOI: 10.5194/hess-14-24152010.

Tiner, R.W. 1989. Wetlands of Rhode island: Newton Coner. Mass., US Fish and Wildlife Service, National Wetlands Inventory, 71.

Tiner, R.W. 1996. Wetland definitions and classifications in the United States. Fretwell, JD et al. (compilers), National Water Summary on Wetland Resources. US Geological Survey. WaterSupply Paper, 2425, 27-34.

Turner, R.K., D. Pearce, and I. Bateman. 1993. Environmental economics: an elementary introduction. Hemel Hempstead, UK: Harvester Wheatsheaf.

Van der Valk. 2012. The biology of freshwater wetlands. New York, USA: Oxford university press.

Verhoeven, J.T.A., B. Beltman, D.F. Whigham, and R. Bobbinnk. 2006. Wetland functioning in a changing world: Implications for natural resources management. Wetlands and Natural Resource Management, 1-12.

Wittig, R. and K.F. Schreiber. 1983. A quick method for assessing two importance of openspace in town for urban nature conservation. Biol. Conserv. 26(1):57-64. DOI: 10.1016/0006-3207(83)90048-4 